\title{
Use of cold microfiltration to produce unique $\beta$-casein enriched milk gels
}

\author{
Diane L. VAN HeKKEN*, Virginia H. Holsinger \\ U.S. Department of Agriculture, Agricultural Research Service, \\ Eastern Regional Research Center, 600 East Mermaid Lane, \\ Wyndmoor, 19038 PA, USA
}

\begin{abstract}
Bovine milk was modified using cold microfiltration to produce $\beta$-casein enriched fractions with unique gelation properties. Skim milk at $4{ }^{\circ} \mathrm{C}$ was microfiltered using membranes with pore diameter of $0.2 \mu \mathrm{m}, 0.1 \mu \mathrm{m}$, or $100000 \mathrm{~g} \cdot \mathrm{mol}^{-1} \mathrm{MWCO}$. Resulting permeates were filtered again using membranes with $10000 \mathrm{~g} \cdot \mathrm{mol}^{-1} \mathrm{MWCO}$ to create retentates with $9 \%$ solids that were used in the gelation study. Ash, calcium, lactose, solids, and protein contents of all fractions were monitored to determine separation trends. Cold microfiltration significantly reduced the casein:whey protein ratio and increased the $\beta$-casein: $\alpha_{\mathrm{s}}$-casein ratio in the retentates from the second filtration; the smaller the pore size of the initial separation membrane, the greater the change in the ratios. When treated with glucono- $\delta$-lactone and rennet, the $\beta$-casein enriched fractions produced using the 0.2 and $0.1 \mu \mathrm{m}$ membranes formed softer gels that had greater syneresis and hydration, and lower water holding capacities than skim milk gels.
\end{abstract}

$\beta$-casein / milk / gelation / microfiltration

\section{INTRODUCTION}

The use of microfiltration in the dairy industry has centered on the removal of microorganisms and the standardization and concentration of solids or caseins in the retentate $[9,13,14]$. While the major empha- sis has been on changing the casein:fat or the casein:whey protein ratios in the fractions, only a few studies have investigated altering the $\alpha_{\mathrm{s} 1}$-casein: $\beta$-casein ratio [17, 19]. In bovine skim milk, the $\alpha_{\mathrm{s} 1}$-casein $\alpha_{\mathrm{s} 2}$-casein: $\beta$-casein: $\kappa$-casein ratio is $4: 1: 4: 1$ [18]. As $\alpha_{\mathrm{s} 1}$-casein contributes the most to

* Correspondence and reprints. dvanhekken@arserrc.gov

Mention of brand or firm name does not constitute an endorsement by the U.S. Department of Agriculture above others of a similar nature not mentioned. 
gel structure and strength, any changes in the amount of $\alpha_{\mathrm{s} 1}$-casein or shifts in the $\alpha_{\mathrm{s} 1}$-casein: $\beta$-casein ratio would alter milk gel properties. Altered protein profiles may also influence the development of flavor and texture as cheeses age. As $\beta$-casein is monomeric and disassociates from the casein micelle at $4{ }^{\circ} \mathrm{C}[2,3,4,18]$, cold microfiltration has been used to produce $\beta$-casein enriched fractions $[17,19]$. The potential of $\beta$-casein enriched fractions for cheese making requires further investigation.

The research reported here characterizes the fractions created with cold microfiltration using membranes with different pore sizes and examines the gelation properties of the $\beta$-casein enriched fractions.

\section{MATERIALS AND METHODS}

\subsection{Microfiltration}

Pasteurized, nonhomogenized, commercial bovine skim milk was obtained locally and was processed according to Woychik [19]. Skim milk was packed in ice and recirculated through a Minitan ${ }^{\mathrm{TM}}$ (Millipore Corp, Beford, MA) ultrafiltration system equipped with a stack of four membranes with pore sizes of either $0.1 \mu \mathrm{m}, 0.2 \mu \mathrm{m}$, or $100000 \mathrm{~g} \cdot \mathrm{mol}^{-1} \mathrm{MWCO}(100 \mathrm{~K})$; total membrane surface area, $240 \mathrm{~cm}^{2}$; flow rate $0.8 \mathrm{~mL} \cdot \mathrm{min}^{-1}$. Milk $(1500 \mathrm{~mL})$ was concentrated four fold to produce approximately $375 \mathrm{~mL}$ of retentate $(1 \mathrm{R})$ and $1125 \mathrm{~mL}$ of permeate (1P). The iced 1P fraction was filtered again using a stack of four membranes with pore size of $10000 \mathrm{~g} \cdot \mathrm{mol}^{-1} \mathrm{MWCO}$ $(10 \mathrm{~K})$ to produce a retentate $(2 \mathrm{R})$ concentrated to $9.0 \%$ solids (approximately $150 \mathrm{~mL}$ ) and $860 \mathrm{~mL}$ of permeate (2P). Initial inlet pressure $(0.41$ to 0.45 bar) increased to an average of 1.6 or 0.58 bar by the end of the first or second filtration step, respectively. Process treatments were done in triplicate and conducted within a $4{ }^{\circ} \mathrm{C}$ chamber.

\subsection{Fraction composition and physical properties}

Composition of skim milk and each fraction generated was determined. Ash was obtained by heating fresh sample in a $550{ }^{\circ} \mathrm{C}$ oven for a minimum of $16 \mathrm{~h}$ (method 945.46) [1]. Moisture was obtained by drying fresh sample at $150{ }^{\circ} \mathrm{C}$ to a constant weight using a Sartorius Moisture Analyzer MA51 (Sartorius Systems, Ltd., New York, NY). Solids-not-fat (SNF) was calculated as $(100-\%$ moisture). Fat content was determined on the initial skim milk using the Babcock procedure (method 989.04) [1]. Nitrogen was determined on lyophilized samples using a FP-2000 Protein-Nitrogen Analyzer (LECO Corp. St.-Joseph, MI) with the combustion furnace set at $1050{ }^{\circ} \mathrm{C}$. Lactose was determined on samples that had been frozen using a lactose/D-galactose assay kit (Boehringer Mannheim, Indianapolis, IN) (method 984.15) [1]. All means were expressed as percentage in fluid sample. Skim milk data were standardized to 9.0\% SNF. Particle size was determined on diluted (1:4) fresh samples using a Submicron Particle Sizer (Autodilute Model 370, NICOMP, Particle Sizing Systems, Santa Barbara, CA). Ash, fat, and lactose were determined in duplicate and moisture, nitrogen, and particle size were determined in triplicate.

Fresh samples were dialyzed, lyophilized, and prepared for standard SDS-PAGE using $20 \%$ homogenous Phast gels on the PhastSystem (Amer. Pharmacia Biotech, Piscataway, NJ). Gels were stained with Coomassie blue and a Personal Densitometer SI equipped with ImageQuaNT version 4.2 software (Molecular Dynamics, Inc., Sunnyvale, CA) was used to quantitate the protein bands identified as caseins $\left(\alpha_{\mathrm{s}^{-}}{ }^{-}\right.$, $\alpha_{\mathrm{s} 2^{-}}, \beta-, \kappa^{-}, \gamma_{1}$, or $\gamma_{2}$-casein) or whey proteins $[\alpha$-lactalbumin $(\alpha$-LA), $\beta$-lactoglobulin $(\beta-\mathrm{LG})$, and minor whey proteins (serum albumin, immunoglobulins, and lactoferrin)]. 


\subsection{Gelation properties}

Gelation properties of skim milk and the $2 \mathrm{R}$ fractions were determined on duplicate samples; except for the $2 \mathrm{R} 100 \mathrm{~K}$ fraction which supplied only one sample per processing treatment. Skim milk samples were standardized to $9.0 \%$ solids with deionized distilled water. Forty $\mathrm{mL}$ of sample were placed in a $50 \mathrm{~mm}$ diameter, wide-mouth plastic jar; warmed in a $30{ }^{\circ} \mathrm{C}$ water bath; and treated with $0.2 \mathrm{~g}$ of glucono- $\delta$-lactone (Sigma Chemical Co., St.-Louis, MO). After 2 min of stirring, sample was incubated at $30{ }^{\circ} \mathrm{C}$ until a pH of 6.0 was obtained. Rennet $(0.08 \mathrm{~mL}$ of single strength rennet, diluted 1/40; Chr. Hanson's Laboratory, Milwaukee, WI) was gently swirled into the sample. After a $0.2 \mathrm{~mL}$ aliquot was removed, the jar was capped and placed in a $30{ }^{\circ} \mathrm{C}$ water bath to gel undisturbed. A test tube containing the $0.2 \mathrm{~mL}$ aliquot was placed at an angle in the $30^{\circ} \mathrm{C}$ water bath and rolled gently. Renneting time was the time it took from the addition of rennet to the first sign of aggregation [10]. Thirty minutes after gelation, the gel strength of the $40 \mathrm{~mL}$ sample was determined using a Texture Analyzer TA.XT2 (Texture Technologies Corp., Scarsdale, NY). A $13 \mathrm{~mm}$ diameter cylindrical probe (TA-10) was lowered into the gel at $1.0 \mathrm{~mm} \cdot \mathrm{sec}^{-1}$ and the force at $4 \mathrm{~mm}$ penetration was measured. The gel was transferred to centrifuge tubes and centrifuged (RC-5B Refrigerated Superspeed Centrifuge with SS-34 rotor; Sorvall Inc., Newtown, CT) at $1086 \times g$ for $10 \mathrm{~min}$ at $10{ }^{\circ} \mathrm{C}$. Syneresis was determined as the percentage $(\mathrm{v} / \mathrm{v})$ of whey expelled from the total gel [5]. The pellet was recentrifuged at $13500 \times g$ for $30 \mathrm{~min}$ at $10{ }^{\circ} \mathrm{C}$ and drained for $10 \mathrm{~min}$ before being weighed and then lyophilized. The water-holding capacity of the gel was determined as the percentage $(\mathrm{w} / \mathrm{w})$ of the pellet (wet weight) in the total gel and the protein hydration was determined as grams of water in the pellet per gram of solids in the pellet [12].

\subsection{Statistical analysis}

Composition and gelation data were analyzed using General Linear Models and mean comparisons were performed using Bonferroni LSD method [15]. Comparisons were described as significant when $P<0.05$.

\section{RESULTS AND DISCUSSION}

\subsection{Composition and physical properties}

Composition of the different fractions is shown in Table I. Compared to skim milk, $1 \mathrm{R}$ had higher and 1P had lower ash, calcium, solids, and protein levels; the $0.1 \mu \mathrm{m}$ and $100 \mathrm{~K} 1 \mathrm{P}$ fractions had higher lactose concentrations. As the membrane pore size decreased, the $1 \mathrm{P}$ fractions became less opaque as the amount of casein passed into the $1 \mathrm{P}$ fraction decreased. The casein:whey protein ratio was high in $1 \mathrm{R}$ and low in $1 \mathrm{P}$ and the opposite was noted for the $\beta$-casein: $\alpha_{s}$-casein ratio. The particles (micelles/submicelles) that passed through the membrane into the $1 \mathrm{P}$ fractions had significantly smaller diameters than those in $1 \mathrm{R}$ and initial milk (Tab. I). This showed that the first cold microfiltration step successfully concentrated the casein micelles in $1 \mathrm{R}$ and allowed only water, whey products, and smaller casein constituents (soluble caseins, submicelles, and small micelles) to enter 1P. The fractionation of milk components using membranes with specific pore sizes to selectively pass certain sized particles into the permeate has been well documented $[13,14]$.

The second ultrafiltration step concentrated $1 \mathrm{P}$ to a retentate $(2 \mathrm{R})$ with $9 \% \mathrm{SNF}$, a solids level common in cheesemaking. The $100 \mathrm{~K}$ samples were so dilute, they could only be concentrated to $8.2 \%$ SNF and still have enough sample for the gelation study. The second step was very effective in concentrating proteins into the $2 \mathrm{R}$ fractions as the $2 \mathrm{P}$ fractions contained less than $0.2 \%$ 
Table I. Means for composition and particle size for skim milk and fractions created using membranes with pores sizes of $0.2 \mu \mathrm{m}, 0.1 \mu \mathrm{m}$, or $100000 \mathrm{~g} \cdot \mathrm{mol}^{-1} \mathrm{MWCO}(100 \mathrm{~K})$ in the first step and concentrating the permeate using membranes with $10000 \mathrm{~g} \cdot \mathrm{mol}^{-1} \mathrm{MWCO}$ in the second step.

\begin{tabular}{|c|c|c|c|c|c|c|}
\hline Fractions & $\begin{array}{l}\text { Ash } \\
(\%)\end{array}$ & Protein & Calcium & $\mathrm{SNF}$ & Lactose & $\begin{array}{l}\text { Particle Size } \\
\quad(\mathrm{nm})\end{array}$ \\
\hline Skim milk & $0.69^{b}$ & $0.12^{\mathrm{b}}$ & $9.0^{c}$ & $4.3^{\mathrm{b}, \mathrm{c}, \mathrm{d}}$ & $3.0^{\mathrm{c}}$ & $158^{b}$ \\
\hline \multicolumn{7}{|l|}{$0.2 \mu \mathrm{m}$} \\
\hline $1 \mathrm{R}$ & $1.29^{\mathrm{a}}$ & $0.32^{\mathrm{a}}$ & $17.5^{b}$ & $4.0^{\mathrm{d}, \mathrm{e}, \mathrm{f}}$ & $10.2^{\mathrm{b}}$ & $159^{b}$ \\
\hline $1 \mathrm{P}$ & $0.48^{\mathrm{d}, \mathrm{e}}$ & $0.05^{\mathrm{c}}$ & $6.6^{\mathrm{f}}$ & $4.6^{\mathrm{a}, \mathrm{b}, \mathrm{c}}$ & $0.7^{\mathrm{d}}$ & $132^{\mathrm{c}}$ \\
\hline $2 \mathrm{P}$ & $0.44^{\mathrm{d}, \mathrm{e}}$ & $0.03^{c}$ & $6.1^{\mathrm{f}, \mathrm{g}}$ & $4.6^{\mathrm{a}, \mathrm{b}}$ & $0.2^{\mathrm{d}}$ & $*$ \\
\hline $2 \mathrm{R}$ & $0.59^{\mathrm{b}, \mathrm{c}}$ & $0.07^{b, c}$ & $9.0^{c}$ & $4.8^{\mathrm{a}}$ & $2.6^{\mathrm{c}}$ & $135^{\mathrm{c}}$ \\
\hline \multicolumn{7}{|l|}{$0.1 \mu \mathrm{m}$} \\
\hline $1 \mathrm{R}$ & $1.34^{\mathrm{a}}$ & $0.34^{\mathrm{a}}$ & $17.6^{a, b}$ & $4.2^{\mathrm{c}, \mathrm{d}, \mathrm{e}}$ & $10.6^{\mathrm{a}, \mathrm{b}}$ & $162^{\mathrm{b}}$ \\
\hline $1 \mathrm{P}$ & $0.51^{\mathrm{c}, \mathrm{d}, \mathrm{e}}$ & $0.05^{\mathrm{c}}$ & $6.5^{\mathrm{f}}$ & $4.7^{\mathrm{a}}$ & $0.7^{\mathrm{d}}$ & $123^{c}$ \\
\hline $2 \mathrm{P}$ & $0.43^{\mathrm{e}}$ & $0.03^{\mathrm{c}}$ & $5.9^{\mathrm{g}}$ & $4.6^{\mathrm{a}, \mathrm{b}, \mathrm{c}}$ & $0.1^{\mathrm{d}}$ & $*$ \\
\hline $2 \mathrm{R}$ & $0.51^{\mathrm{c}, \mathrm{d}, \mathrm{e}}$ & $0.07^{b, c}$ & $8.9^{\mathrm{c}, \mathrm{d}}$ & $4.6^{\mathrm{a}, \mathrm{b}, \mathrm{c}}$ & $2.9^{c}$ & $125^{\mathrm{c}}$ \\
\hline \multicolumn{7}{|l|}{$100 \mathrm{~K}$} \\
\hline $1 \mathrm{R}$ & $1.32^{\mathrm{a}}$ & $0.30^{\mathrm{a}}$ & $18.2^{\mathrm{a}}$ & $3.9^{\mathrm{e}, \mathrm{f}}$ & $11.1^{\mathrm{a}}$ & $153^{\mathrm{b}}$ \\
\hline $1 \mathrm{P}$ & $0.49^{\mathrm{c}, \mathrm{d}, \mathrm{e}}$ & $0.03^{c}$ & $6.2^{\mathrm{f}, \mathrm{g}}$ & $4.8^{\mathrm{a}}$ & $0.3^{\mathrm{d}}$ & $*$ \\
\hline $2 \mathrm{P}$ & $0.45^{\mathrm{d}, \mathrm{e}}$ & $0.03^{c}$ & $5.9^{\mathrm{g}}$ & $4.6^{\mathrm{a}, \mathrm{b}, \mathrm{c}}$ & $0.2^{\mathrm{d}}$ & $*$ \\
\hline $2 \mathrm{R}$ & $0.53^{\mathrm{c}, \mathrm{d}}$ & $0.03^{c}$ & $8.2^{\mathrm{e}}$ & $4.7^{a}$ & $2.6^{c}$ & $*$ \\
\hline RMSE & 0.05 & 0.03 & 0.36 & 0.19 & 0.44 & 7 \\
\hline
\end{tabular}

* No particles detected in undiluted sample.

a, b, c, d, e, f, g Means in the same column that do not share similar letters are significantly $(P<0.05)$ different.

Permeate from first step, 1P; permeate from second step, $2 \mathrm{P}$; retentate from first step, $1 \mathrm{R}$; retentate from second step, 2R; root mean square for error, RMSE; solids-not-fat, SNF.

protein. Total protein levels for the $2 \mathrm{R}$ fractions were similar to skim milk, while the ash and calcium contents tended to be lower and the lactose concentration higher. This concentration of protein in the retentate and production of a permeate with little protein is typical of ultrafiltration $[13,14]$.

The differences in protein profiles between skim milk and $2 \mathrm{R}$ fractions are shown in Figure 1 and protein ratios are given in Table II. The SDS-PAGE gel show the decrease in $\alpha_{\mathrm{S}^{-}}$-casein $\left(\alpha_{\mathrm{s} 1^{-}}\right.$and $\alpha_{\mathrm{s} 2^{-}}$ casein) and the increase in the major whey proteins as pore size decreased. The purity of $\beta$-casein ( $\% \quad \beta$-casein in total casein) increased from $38.6 \%$ in skim milk to 52.3 , 60.8 , and $75.0 \%$ in the $0.2 \mu \mathrm{m}, 0.1 \mu \mathrm{m}$, and
$100 \mathrm{~K} 2 \mathrm{R}$ fractions. This purity range was similar to the $60 \%$ (maximum) $\beta$-casein fractions obtained by Le Berre and Daufin [8] by ultrafiltering ( 0.02 to $0.08 \mu \mathrm{m}$ membrane pore sizes) dilute $(1 \%)$ sodium caseinate solutions at $4{ }^{\circ} \mathrm{C}$. Casein:whey protein ratios decreased from skim milk to $2 \mathrm{P}$ fractions and as membrane pore size decreased. The $\beta$-casein: $\alpha_{S}$-casein ratios for the $2 \mathrm{R}$ fractions were larger than skim milk and increased as pore size decreased. The $\beta$-casein: $\kappa$-casein ratios were significantly higher in the filtered fractions with $100 \mathrm{~K}$ fraction having the highest ratio. The $\alpha_{\mathrm{s}}$-casein: $\kappa$-casein ratios were not significantly different between skim milk and the $2 \mathrm{R}$ fractions, although the $100 \mathrm{~K}$ fraction 


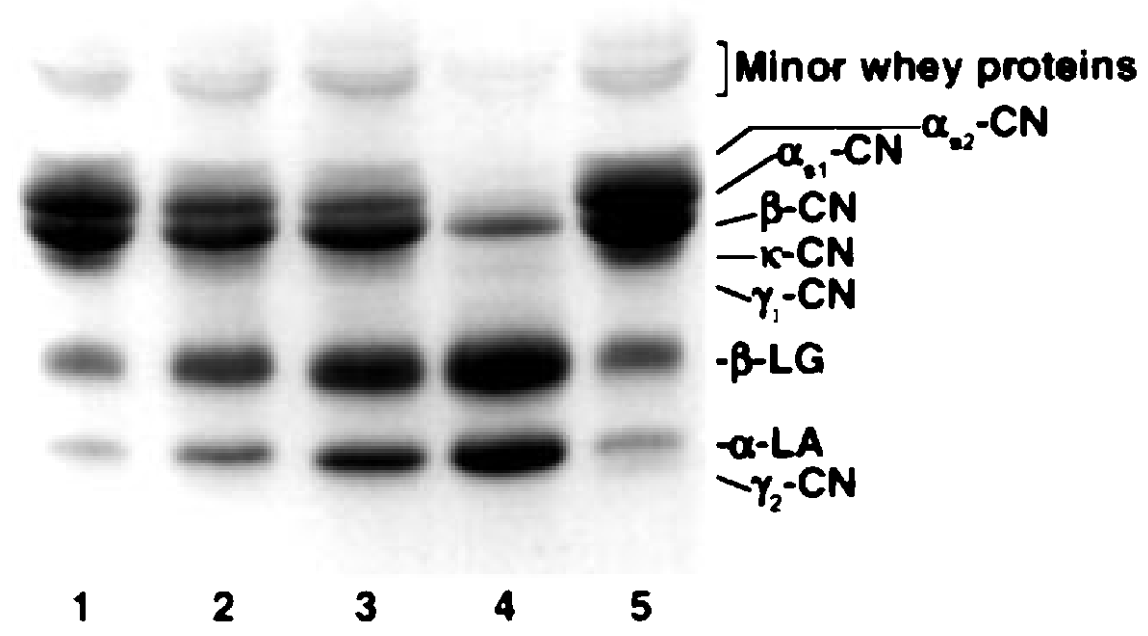

Figure 1. SDS-PAGE of skim milk (lanes 1 and 5) and $2 \mathrm{R}$ fractions from cold microfiltration using membranes with pore sizes of $0.2 \mu \mathrm{m}$ (lane 2), $0.1 \mu \mathrm{m}$ (lane 3), or $100000 \mathrm{~g} \cdot \mathrm{mol}^{-1} \mathrm{MWCO}$ (lane 4) in the first step and concentrating the permeate using membranes with $10000 \mathrm{~g} \cdot \mathrm{mol}^{-1} \mathrm{MWCO}$ in the second step. Proteins were separated on $20 \%$ homogeneous gels using SDS-PAGE and stained with Coomassie blue. Casein, CN; lactalbumin, LA; lactoglobulin, LG.

tended to be higher. Our fractionation results were similar to an earlier report by Woychik [19], although our 100K 2R fraction contained less $\beta$-casein and more $\alpha$-LA.

Earlier research had shown that $\beta$-casein disassociated from casein micelles at $4{ }^{\circ} \mathrm{C}$ $[2,11]$. Also, the casein composition of the micelle differed with its size and that the larger micelles contained more $\beta$-casein and less $\kappa$-casein $[2,11]$. Ono et al. [11] reported that $\beta$-casein, $\kappa$-casein, and calcium phosphate left casein micelles at $4{ }^{\circ} \mathrm{C}$ with micelles over $100 \mathrm{~nm}$ in diameter losing the most $\beta$-casein, micelles under $60 \mathrm{~nm}$ in diameter losing the most $\kappa$-casein, and $83 \%$ of the soluble casein was $\beta$-casein.

The problems with cold microfiltration have been the difficulty in maintaining temperature due to heat generated by friction as sample cycled through the system and with increased viscosity of the retentate due to reduced temperature and increased solids [7]. In our study, temperature of $1 \mathrm{R}$ was maintained at $4{ }^{\circ} \mathrm{C}\left( \pm 2{ }^{\circ} \mathrm{C}\right)$ by packing the retentate in ice and operating the system in a $4{ }^{\circ} \mathrm{C}$ chamber. By the end of the first step, the flow rate had not changed while the viscosity of $1 \mathrm{R}$ had increased and the line pressure had tripled but not exceeded its limit. These will be concerns when this process is scaled-up for pilot plant studies.

\subsection{Gelation properties}

The $100 \mathrm{~K}$ membrane was very effective at removing only whey proteins from skim milk. Not enough casein was present in the $100 \mathrm{~K} 2 \mathrm{R}$ fraction (total casein averaged $0.3 \%$ ) to form a gel when treated with acid and rennet. This fraction will not be discussed further. Our 0.2 and $0.1 \mu \mathrm{m} 2 \mathrm{R}$ fractions contained 1.1 and $0.9 \%$ casein, respectively, and formed gels as they were close to the $1 \%$ casein minimum generally required for gelation [4].

Gelation properties for the skim milk and $2 \mathrm{R}$ fractions are shown in Table II. Skim milk and $0.2 \mu \mathrm{m} 2 \mathrm{R}$ fractions had similar renneting times, while the $0.1 \mu \mathrm{m} 2 \mathrm{R}$ 
Table II. Protein distribution and gelation properties of skim milk and second retentate (2R) fractions made using membranes with pore sizes of $0.2 \mu \mathrm{m}$ $0.1 \mu \mathrm{m}$, or $100000 \mathrm{~g} \cdot \mathrm{mol}^{-1}$ molecular weight cut-off $(100 \mathrm{~K})$.

\begin{tabular}{|c|c|c|c|c|c|c|c|c|c|}
\hline \multirow{3}{*}{ Fractions } & \multicolumn{4}{|c|}{ Protein Distribution } & \multicolumn{5}{|c|}{ Gelation Properties } \\
\hline & \multirow[t]{2}{*}{$\begin{array}{l}\text { Casein: } \\
\text { Whey } \\
\text { Protein }\end{array}$} & \multirow[t]{2}{*}{$\begin{array}{l}\beta \text {-casein: } \\
\alpha_{\mathrm{s}} \text {-casein }\end{array}$} & \multirow[t]{2}{*}{$\begin{array}{l}\beta \text {-casein: } \\
\kappa \text {-casein }\end{array}$} & \multirow[t]{2}{*}{$\begin{array}{c}\alpha_{\mathrm{s}} \text {-casein } \\
\kappa \text {-casein }\end{array}$} & \multirow[t]{2}{*}{$\begin{array}{l}\text { Renneting } \\
\text { Time } \\
\text { (min) }\end{array}$} & \multirow[t]{2}{*}{$\begin{array}{c}\text { Gel } \\
\text { Strength } \\
\text { (g Force) }\end{array}$} & Syneresis & $\begin{array}{l}\text { Water } \\
\text { Holding } \\
\text { Capacity }\end{array}$ & \multirow[t]{2}{*}{$\begin{array}{c}\text { Hydration } \\
\text { (g water/ } \\
\text { g solids) }\end{array}$} \\
\hline & & & & & & & \multicolumn{2}{|c|}{$\%$} & \\
\hline Skim Milk & $2.5: 1^{\mathrm{a}, \mathrm{b}}$ & $0.8: 1^{\mathrm{e}, \mathrm{f}}$ & $2.9: 1^{b}$ & $3.5: 1^{\mathrm{a}}$ & $4.89^{b}$ & $4.54^{\mathrm{a}}$ & $79.6^{\mathrm{c}}$ & $8.20^{\mathrm{a}}$ & $1.83^{\mathrm{c}}$ \\
\hline $0.2 \mu \mathrm{m}$ & $0.7: 1^{b, c}$ & $1.4: 1^{\mathrm{d}, \mathrm{e}, \mathrm{f}}$ & $8.4: 1^{\mathrm{a}}$ & $4.8: 1^{\mathrm{a}}$ & $4.93^{\mathrm{b}}$ & $1.59^{\mathrm{b}}$ & $88.0^{\mathrm{a}, \mathrm{b}}$ & $4.82^{\mathrm{b}}$ & $2.07^{\mathrm{b}}$ \\
\hline $0.1 \mu \mathrm{m}$ & $0.4: 1^{\mathrm{c}}$ & $2.2: 1^{\mathrm{c}, \mathrm{d}, \mathrm{e}}$ & $8.2: 1^{\mathrm{a}}$ & $3.5: 1^{\mathrm{a}}$ & $8.63^{\mathrm{a}}$ & $1.20^{\mathrm{b}}$ & $90.8^{\mathrm{a}}$ & $5.24^{\mathrm{b}}$ & $2.81^{\mathrm{a}}$ \\
\hline $100 \mathrm{~K}$ & $0.1: 1^{\mathrm{c}}$ & $4.0: 1^{\mathrm{a}, \mathrm{b}}$ & $12.0: 1^{\mathrm{a}}$ & $6.3: 1^{\mathrm{a}}$ & $* *$ & $* *$ & $* *$ & $* *$ & $* *$ \\
\hline RMSE & 0.7 & 0.58 & 2.02 & 1.69 & 0.70 & 0.38 & 2.6 & 0.39 & 0.14 \\
\hline
\end{tabular}

** Fraction did not form gel.

$\mathrm{a}, \mathrm{b}, \mathrm{c}, \mathrm{d}, \mathrm{e}, \mathrm{f}$ Means in the same column that do not share similar letters are significantly $(P<0.05)$ different. Root mean square for error, RMSE 
fraction took almost twice as long to coagulate. The $2 \mathrm{R}$ gels were similar in gel strength, syneresis, and water holding capacities but, when compared to skim milk gels, had significantly lower gel strengths and were less able to hold fluid in their gel matrices as seen by greater syneresis and lower water holding capacities. Protein hydration was significantly different for each fraction and increased as pore size decreased.

The gelation of milk is based on the destabilization of casein micelles $[4,6,16$, 17]. Chymosin, the key enzyme in rennet, removes the 'hairy' portion of $\kappa$-casein located at the surface of the micelle [6]. When enough $\kappa$-casein has been hydrolyzed to reduce the stearic repulsion of the micelle, the destabilized micelles aggregate together in irregular chains to form a matrix with large spaces that entrapped fluids and other solids.

Gelation properties have been influenced by many factors: $\mathrm{pH}$, temperature, protein and/or calcium concentration, and the type and amount of added acid and/or coagulation enzyme $[4,16]$. Renneting time was related to quantity of $\kappa$-casein available for hydrolysis and quantity of casein available to aggregate. Denatured whey proteins also have been reported to block or slow gelation, usually through $\kappa$-casein and $\beta$-LG interactions or through interference in the ionic bonds [4, 16]. Most likely the increased quantity of whey protein and decreased available casein in the $0.1 \mu \mathrm{m} 2 \mathrm{R}$ fraction contributed to slower renneting time, but it is not clear why the $0.2 \mu \mathrm{m}$ fraction had renneting time similar to skim milk.

Gel strength, syneresis, water holding capacity, and protein hydration all involve protein-protein and protein-water interactions. Although the $\alpha_{S}$-casein: $\kappa$-casein ratios were not significantly different between samples, the 0.2 and $0.1 \mu \mathrm{m} 2 \mathrm{R}$ fractions had $\beta$-casein: $\alpha_{S}$-casein ratios that were 2 and 4 fold greater and $\beta$-casein: $\kappa$-casein ratios were almost 3 fold greater than those found in skim milk. The shift in $\beta$-casein: $\alpha_{S}$-casein and $\beta$-casein: $\kappa$-casein ratios reflect the alterations in the gelation properties and require further study. Reduced quantity of caseins, increased concentration of the hydrophobic beta-casein, and increased concentration of whey proteins present in our fractions also would contribute to the significant changes seen in these gelation properties. Altered properties would also lead to changes in a variety of cheesemaking characteristics including curd strength/shattering, yield, moisture, and, ultimately, aging.

\section{CONCLUSIONS}

The dairy industry is always searching for novel cheese products to cater to the consumer's desire for unique tastes and texture. This study showed that cold microfiltration of bovine milk using membranes with different pore sizes created fractions that contained different $\beta$-casein: $\alpha_{\mathrm{s}}$-casein ratios. The $2 \mathrm{R}$ fractions created from the use of the 0.2 and $0.1 \mu \mathrm{m}$ membranes had unique gelation properties that suggest they may be used as the starting material in the production of novel soft cheeses.

\section{ACKNOWLEDGMENTS}

Authors thankfully acknowledge J.G. Phillips for his statistical help in analyzing data and S. Clauson for her help in composition analysis.

\section{REFERENCES}

[1] AOAC, Official Methods of Analysis, 15th ed. Assoc. of Official Analytical Chemists, Washington, DC. Methods 945.46, 984.15, and 989.04, 1990.

[2] Davies D.T., Law A.J.R., Variation in the protein composition of bovine casein micelles and serum casein in relation to micellar size and milk temperature, J. Dairy Res. 50 (1983) 67-75.

[3] Famelart M.H., Hardy C., Brulé G., Factors affecting the extraction of $\beta$-casein, Lait 69 (1989) 47-57. 
[4] Fox P.F., Mulvihill D.M., Casein, in: P. Harris (Ed.), Food Gels, Elsevier, London, 1990, pp. 121-173.

[5] Harwalkar V.R., Kalab M, Susceptibility of yoghurt to syneresis. Comparison of centrifugation and drainage methods, Milchwissenschaft 38 (1983) 517-522.

[6] Holt C., Horne D.S., The dairy casein micelle: Evolution of the concept and implications for dairy technology, Neth. Milk Dairy J. 50 (1996) $85-111$.

[7] Kapsimalis D.J., Zall R.R., Ultrafiltration of skim milk at refrigerated temperatures, J. Dairy Sci. 64 (1981) 1945-1950.

[8] Le Berre O., Daufin G., Fouling and selectivity of membrane during separation of $\beta$-casein, J. Membrane Sci. 88 (1994) 263-270.

[9] Maubois J.L., Recent developments in membrane technology, Latte 22 (1997) 186-191.

[10] McMahon D.J., Brown R.J., Richardson G.H., Ernstrom C.A., Effects of calcium, phosphate, and bulk culture media on milk coagulation properties, J. Dairy Sci. 67 (1984) 930-938.

[11] Ono T., Murayama T., Kaketa S., Odagiri S., Changes in the protein composition and size distribution of bovine casein micelles induced by cooling, Agric. Biol. Chem. 54 (1990) 1385-1392.
[12] Parnell-Clunies E.M., Kakuda Y., Mullen K., Arnott D.R., deMan J.M., Physical properties of yogurt: A comparison of vat versus continuous heating systems of milk, J. Dairy Sci. 69 (1986) 2593-2603.

[13] Renner E., Abd El-Salam M.H., in: Application of ultrafiltration in the dairy industry, Elsevier, NY, 1991.

[14] Rosenberg M., Current and future applications for membrane processing in the dairy industry, Trends Food Sci. Technol. 6 (1995) 12-19.

[15] SAS Institute, SAS/STAT User's Guide, Version 6.12 for Windows, Vol. 2, 4th ed., SAS Institute, Cary NC, 1989.

[16] Schmidt R.H., Morris H.A., Gelation properties of milk proteins, soy proteins, and blended protein systems, Food Technol. 38 (1984) 85-96.

[17] Terre E., Maubois J.L., Brulé G., Pierre A., Manufacture of a composition enriched with $\beta$-casein, French patent No. $2592769,1986$.

[18] Walstra P., On the stability of casein micelles, J. Dairy Sci. 73 (1990) 1965-1979.

[19] Woychik J.H., Preparation of simulated human milk protein by low temperature microfiltration, US Patent No. 5169666, 1992. 